DOI:

Лілія Полещук, завідувач відділу освітньо-наукової підготовки КЗВО “Одеська академія неперервної освіти Одеської обласної ради”

\title{
ПЕДАГОГІЧНІ УМОВИ ФОРМУВАННЯ ПРОФЕСІЙНО-ЗНАЧУЩИХ ЯКОСТЕЙ МАЙБУТНІХ МЕНЕДЖЕРІВ ОСВІТИ
}

Стаття присвячена аналізу педагогічних умов, щзо впливають на формування професійно-значущих якостей менеджерів освіти. Проаналізовано поняття "педагогічна умова" з позииії філософії, психологіі та педагогіки. Схарактеризовано класифікаиійні групи педагогічних умов. Уточнено поняття "педагогічні умови”, котрі розглядаються як сукупність причин, обставин, будь-яких об'єктів, щяо впливають на функиіонування і розвиток будь-якого об'єкта (педагогічної системи, иілісного педагогічного процесу). Встановлено, що процес формування професійно-значущих якостей майбутніх менеджерів освіти може бути продуктивним за умови проєктування та впровадження комплексу педагогічних умов.

Ключові слова: менеджер освіти; професійно-значущі якості формування; педагогічні умови; професійна підготовка.

Табл. 1. Літ. 14.

Liliya Poleshchuk, Head of the Educational and Scientific Training Department Odessa Regional Academy of In-Service Education

\section{PEDAGOGICAL CONDITIONS OF FORMATION PROFESSIONAL-SIGNIFICANT QUALITIES EDUCATION MANAGER}

In the conditions of modernization of the system of higher professional education special attention is paid to the problem of formation of competence of the future manager of education. Modern society needs heads of educational institutions capable of effective management. In this regard, the issues offormation and development of professionally significant qualities of education managers, which determine the effectiveness of management, are relevant. However, the analysis of pedagogical literature and the experience of professional activity of graduates of pedagogical universities showed that they are not always actively involved as subjects of activity in the process of self-development of professionally significant personal qualities. Purpose of the article is: To analyze and generalize approaches, to clarify the concept of "pedagogical conditions", to characterize organizational-pedagogical, psychologicalpedagogical, didactic conditions. Theoretically substantiate the feasibility of integrated use of pedagogical conditions for the formation of professionally significant qualities of future educational managers, to propose a set of pedagogical conditions. In the context of research, a set of pedagogical conditions means external and internal circumstances, educational and training activities that ensure the achievement of the specific goal of forming the professionally significant qualities of the future education manager. The process of forming professionally significant qualities of a future education manager can be productive provided that a set of conditions is involved, because disparate conditions cannot solve a certain goal effectively. When developing a set of pedagogical conditions it is necessary to take into account the influence of factors: the social order of society in the system of higher professional education in the context of the researched problem; specifics and opportunities for professional development of the individual in the context of the relationship of external and internal subsystems; the need to implement organizational and pedagogical requirements and the relationship of systemic, differentiated, technological and competency approaches. It is determined that the set of pedagogical conditions for the formation of professionally significant qualities of an educational manager are: individualization of training in the system of subject-subject relations, use of managerial potential of future educational managers in the educational process, maximally aimed at forming professionally significant qualities; a system of educational-methodical, technological support and support of the educational process, aimed at the formation of professionally significant qualities of educational managers; inclusion and motivation of the teaching staff to form professionally significant qualities of education managers.

Keywords: an education manager; professionally significant qualities of formation; pedagogical conditions; professional training.

П остановка проблеми. В умовах модернізації системи вищої професійної освіти особлива увага надається проблемі формування компетентності майбутнього менеджера освіти. Сучасному суспільству необхідні керівники закладів освіти, здатні до ефективної управлінської діяльності. У зв'язку з цим актуалізуються питання формування і розвитку професійно-значущих якостей менеджерів освіти, які визначають ефективність управлінської діяльності. Однак аналіз педагогічної літератури та досвід професійної діяльності випускників педагогічних університетів показав, що вони не завжди активно включаються 


\section{ПЕДАГОГІЧНІ УМОВИ ФОРМУВАННЯ ПРОФЕСІЙНО-ЗНАЧУЩИХЯКОСТЕЙ МАЙБУТНІХМЕНЕДЖЕРІВ ОСВІТИ}

як суб'єкти діяльності у процес саморозвитку професійно-значущих особистісних якостей.

Процес формування професійно-важливих якостей майбутніх менеджерів освіти у процесі професійної підготовки вимагає створення відповідного комплексу педагогічних умов.

Аналіз основних досліджень і публікацій. Проблема умов розглядалася у дослідженнях В. Андрєєва, А. Найна, Н. Іпполітова, М. Звєревої, Б. Купріянова, С. Диніної та ін. Питанням організаційно-педагогічних умов займалися В. Беліков, Є. Козирєва, С. Павлов, А. Цвіркунів i ін. Психолого-педагогічні умови розглядали Н. Журавська, А. Круглий, А. Лисенко, А. Малихін і ін. Дидактичні умови досліджували М. Рутковська, Н. Яковлєва і ін.

Мета статті. Проаналізувати й узагальнити підходи, уточнити поняття педагогічні умови. Схарактеризувати організаційно-педагогічні, психолого-педагогічні, дидактичні умови; теоретично обгрунтувати доцільність комплексного використання педагогічних умов формування професійно-значущих якостей майбутніх менеджерів освіти, запропонувати комплекс педагогічних умов формування професійно-значущих якостей майбутніх менеджерів освіти.

Виклад основного матеріалу. Процес формування професійно-значущих якостей майбутніх менеджерів освіти вимагає створення комплексу педагогічних умов.

Логіка започаткованого дослідження вимагає розглянути поняття "умова", “педагогічні умови”.

3 філософської позиції це поняття пов’ язане 3 відношенням предмета до явищ що його оточують, без яких він існувати не може: “те, від чого залежить щось інше (що обумовлюється); істотний компонент комплексу об'єктів (речей, їх станів, взаємодій), 3 наявності якого 3 необхідністю випливає існування даного явища". Тобто сукупність конкретних умов певного явища утворює середовище його протікання, виникнення, існування і розвитку.

У психології поняття “умова” представлене у контексті психічного розвитку і розкривається через сукупність внутрішніх і зовнішніх чинників, що визначають психологічний розвиток людини, що прискорюють або уповільнюють його та впливають на процес розвитку, його динаміку та кінцеві результати.

У педагогіці умова розглядається як сукупність змінних природних, соціальних, зовнішніх і внутрішніх чинників, що впливають на фізичний, моральний, психічний розвиток людини, ії поведінку, виховання і навчання, формування особистості.
Сутність поняття “умова" в педагогічному аспекті характеризується як:

- сукупність причин, обставин, будь-яких об'єктів тощо;

- визначена сукупність, що впливає на розвиток, виховання та навчання людини;

- вплив умов що прискорює або сповільнює процеси розвитку, виховання і навчання, а також впливає на їх динаміку і кінцеві результати.

Ю. Бабанський виділяє дві групи умов функціонування педагогічної системи: зовнішні (природно-географічні, суспільні, виробничі, культурні, середовище мікрорайону) і внутрішні (навчально-матеріальні, шкільно-гігієнічні, морально-психологічні, естетичні).

За специфікою об'єкта впливу виділяють загальні та специфічні умови, що сприяють функціонуванню і розвитку педагогічної системи. До загальних умов належать соціальні, економічні, культурні, національні, географічні та ін. умови; до специфічних - особливості соціальнодемографічного складу учнів; місцезнаходження закладу освіти; матеріальні можливості освітнього закладу, обладнання освітнього процесу; виховні можливості навколишнього середовища тощо. Важливу роль у забезпеченні функціонування та розвитку педагогічної системи відіграють також такі специфічні умови, як: характер морально-психологічної атмосфери у педагогічному та учнівському колективах, рівень педагогічної культури педагогів тощо.

При визначенні напрямів розвитку педагогічної системи певну роль відіграє врахування просторових умов, в яких існує педагогічна система, тому що iï функціонування обумовлюється особливостями регіональних, місцевих умов, специфікою закладу освіти, конкретного педагогічного середовища, рівнем кваліфікації необхідних педагогічних кадрів, рівнем оснащеності освітнього процесу (кабінети, навчальні посібники, обладнання тощо.).

У психолого-педагогічній літературі поняття “умови” розглядається часто як видова щодо родових понять “середовище”, “обставини”, “обстановка” (В. Андреєв, Р. Низамов).

Педагогічні умови досліджували В. Андреєва, А. Найна, Н. Яковлєва, Н. Іпполітова, М. Звєрева, Б. Купріянова, С. Диніна та ін., розглядаючи це поняття з різних підходів.

В. Андреєв, А. Найн, Н. Яковлєва визначають педагогічні умови як сукупність будьяких заходів педагогічного впливу і можливостей матеріальнопросторового середовища:

- зміст, методи (прийоми) і організаційні форми навчання і виховання; 


\section{ПЕДАГОГІЧНІ УМОВИ ФОРМУВАННЯ ПРОФЕСІЙНО-ЗНАЧУЩИХ ЯКОСТЕЙ МАЙБУТНІХМЕНЕДЖЕРІВ ОСВІТИ}

- сукупність об'єктивних можливостей змісту, форм, методів, засобів і матеріальнопросторового середовища, спрямованих на розв'язання поставлених завдань;

- сукупність заходів (об'єктивних можливостей) педагогічного процесу.

Н. Житнік визначено і досліджено педагогічні умови, що забезпечують якісну професійну підготовку фахівців, а саме: реалізацію змісту освіти; методичне забезпечення навчально-виховного процесу; впровадження інноваційних навчальних технологій; забезпечення особистісноорієнтованого підходу в організації навчання; стан виховної роботи у вищій школі; професійну майстерність викладачів [3].

Н. Іпполітова, М. Звєрева, пов'язують педагогічні умови з конструюванням педагогічної системи, у котрій педагогічні умови виступають одним із компонентів:

- компонент педагогічної системи, що відображає сукупність внутрішніх (забезпечують розвиток особистісного аспекту суб'єктів освітнього процесу) і зовнішніх (сприяють реалізації процесуального аспекту системи) елементів, що забезпечують їі ефективне функціонування і подальший розвиток;
- змістова характеристика одного 3 компонентів педагогічної системи, якою виступають зміст, організаційні форми, засоби навчання і характер взаємин між учителем і учнями.

Б. Купріянов, С. Диніна визначають педагогічні умови як планомірну роботу з уточнення закономірностей, як стійких зав'язків освітнього процесу, що забезпечує перевіреність результатів науково-педагогічного дослідження.

Дослідники виділяють види педагогічних умов, що забезпечують функціонування і ефективний розвиток педагогічної системи: організаційнопедагогічні, психолого-педагогічні, дидактичні умови, що узагальнено представлено у таблиці 1.

Як засвідчує таблиця, педагогічні умови характеризують: сукупність можливостей освітнього та матеріально-просторового середовища, що сприяє підвищенню ефективності педагогічного процесу; сукупність заходів впливу спрямованих на розвиток особистості суб'єктів педагогічної системи та забезпечення успішного розв'язання завдань педагогічного процесу.

Основною функцією психолого-педагогічних

Таблиця 1.

\begin{tabular}{|c|c|c|c|}
\hline & Автор & Визначення & Джерела \\
\hline \multirow{6}{*}{ 范 } & О. Козирева & $\begin{array}{l}\text { сукупність об’єктивних можливостей, забезпечує успішне } \\
\text { рішення поставлених завдань. }\end{array}$ & [5] \\
\hline & В. Беліков & $\begin{array}{l}\text { сукупність можливостей змісту, форм, методів цілісного } \\
\text { педагогічного процесу, спрямованих на досягнення цілей } \\
\text { педагогічної діяльності. }\end{array}$ & [1] \\
\hline & С.Павлов & $\begin{array}{l}\text { сукупність об’єктивних можливостей навчання та виховання } \\
\text { населення, організаційних форм і матеріальних } \\
\text { можливостей, а також такі обставини взаємодії суб'єктів } \\
\text { педагогічної взаємодії, які є результатом цілеспрямованого, } \\
\text { планованого відбору, конструювання та застосування } \\
\text { елементів змісту, методів (прийомів) для досягнення мети } \\
\text { педагогічної діяльності. }\end{array}$ & [9] \\
\hline & К. Дубич & $\begin{array}{l}\text { визначає як } \\
\text { взаємообумовлених }\end{array}$ & [2] \\
\hline & В. Стасюк & 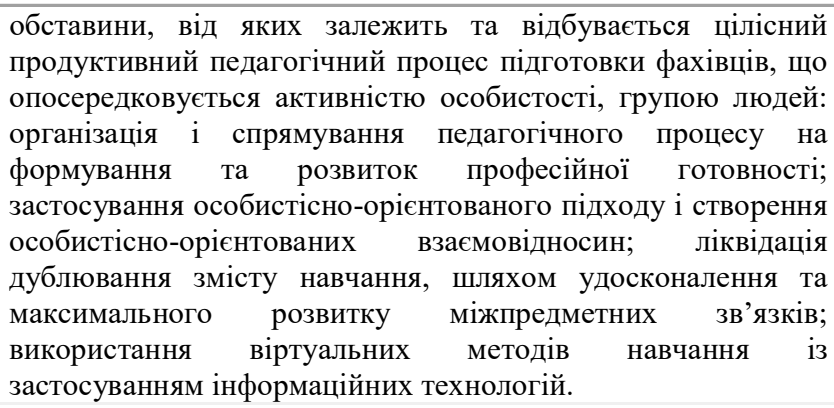 & [13] \\
\hline & О. Сверчков & $\begin{array}{l}\text { принципові підстави для зв’язування процесів діяльності } 3 \\
\text { управління процесом формування професійно-педагогічної } \\
\text { культури особистості. }\end{array}$ & [12] \\
\hline
\end{tabular}




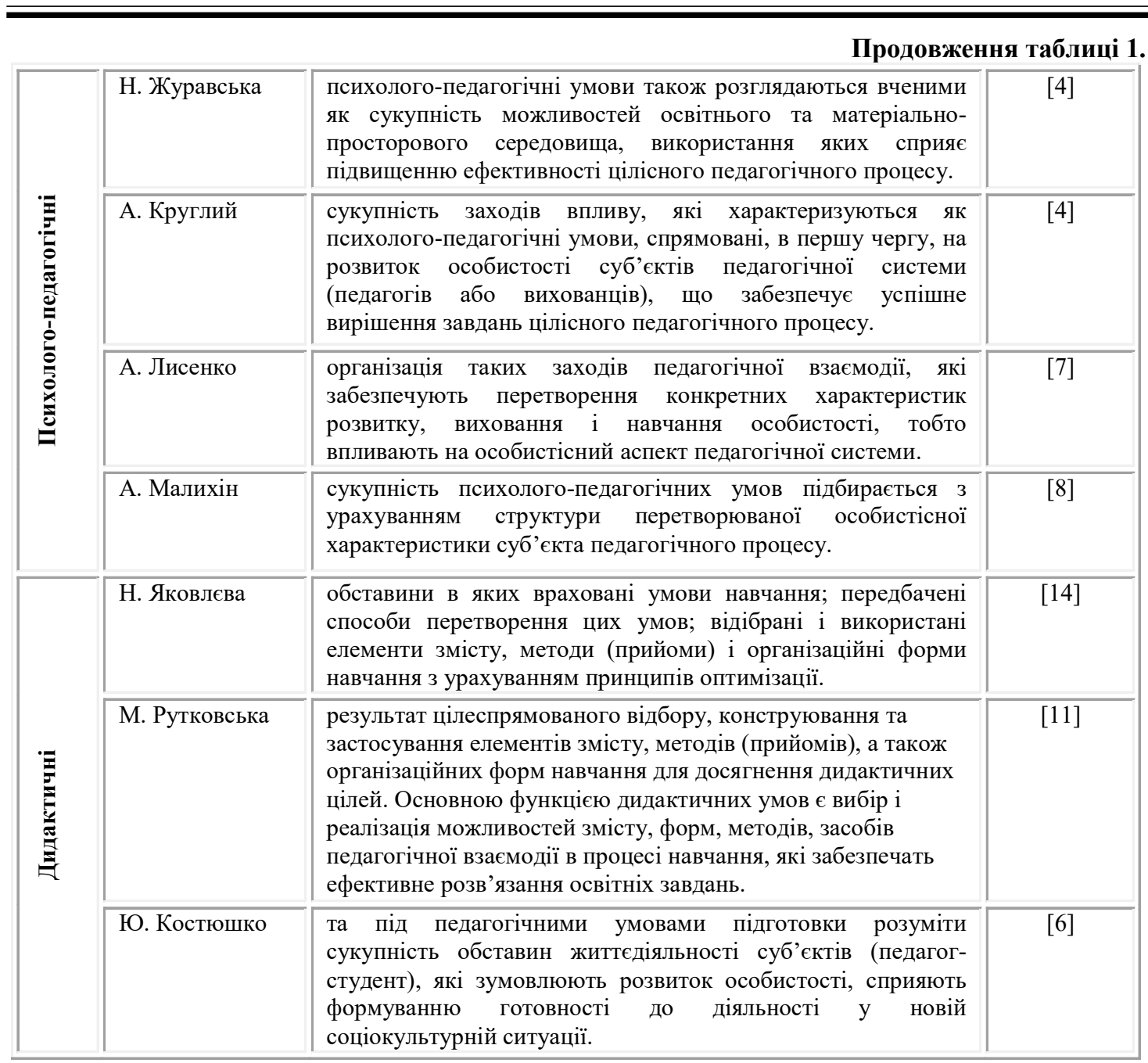

умов є організація педагогічної взаємодії, що забезпечує розвиток, виховання і навчання особистості. Психолого-педагогічні умови проєктуються, враховуючи особистість суб'єкта педагогічного процесу.

Основною функцією дидактичних умов є вибір і реалізація можливостей змісту, форм, методів, засобів педагогічної взаємодії у процесі навчання, що забезпечать ефективне розв'язання освітніх завдань.

Отже, у результаті аналізу науковопедагогічних джерел встановлено, що умова - це сукупність причин, обставин, будь-яких об'єктів, що впливають на функціонування і розвиток будьякого об'єкта (педагогічної системи, цілісного педагогічного процесу).

У контексті дослідження під комплексом педагогічних умов розуміємо зовнішні і внутрішні обставини, виховні та освітні заходи, що забезпечують досягнення конкретної мети формування професійно-значущих якостей майбутнього менеджера освіти.
У словнику С.Ожегова “комплекс - це сукупність, поєднання чого-небудь”. У філософському енциклопедичному словнику комплекс (від лат. complexion - зв'язування, з'єднання) представлений $з$ психологічного підходу як монолітного ціле, на противагу “гештальту”, що є структурованим з елементів цілим, наприклад, комплекс уявлень.

За О. Авер'яновим, комлексність - це специфічна форма конкретизації системності. Сутність реалізації комплексу умов полягає в єдності цілей і завдань, принципів, змісту, форм і методів роботи. На думку дослідника, створення комплексу умов, по суті, є практичною реалізацією системного, діяльнісного підходу, а отже, вносить певні нюанси у розуміння системи, говорить про характер - статистичне або динамічне об'єднання компонентів у системі.

Характеризуючи комплекс педагогічних умови, необхідно враховувати позицію Н. Яковлєвої, яка вважає, що ефективність виділених умов залежить від чітко сформульованої кінцевої мети або 


\section{ПЕДАГОГІЧНІ УМОВИ ФОРМУВАННЯ ПРОФЕСІЙНО-ЗНАЧУЩИХ ЯКОСТЕЙ МАЙБУТНІХМЕНЕДЖЕРІВ ОСВІТИ}

результату та функціонування і вдосконалення педагогічного процесу, що досягається за рахунок взаємопов'язаного комплексу умов.

На думку К. Роджерса, будьяка якість особистості - не чисте знання і досвід, а тому може бути розвиненою за умови створення для цього певних умов [10].

Проєктуючи комплекс педагогічних умов формування професійно-значущих якостей менеджерів освіти у процесі магістерської підготовки, враховано вплив чинників, зокрема: соціального замовлення суспільства системі вищої професійної освіти щодо підготовки менеджерів освіти; специфіки і можливостей професійного розвитку особистості у контексті взаємозв'язку зовнішньої та внутрішньої підсистем; необхідності реалізації організаційнопедагогічних вимог і взаємозв'язку системного, диференційованого, технологічного та компетентнісного підходів.

Виходячи з вищезазначеного, комплекс педагогічних умов формування професійнозначущих якостей менеджера освіти у процесі магістерської підготовки склали:

- індивідуалізація навчання у системі суб'єктсуб'єктних відносин з використанням управлінського потенціалу майбутніх менеджерів в освітньому процесі максимально спрямованих на формування професійно-значущих якостей особистості;

- система навчально-методичного, технологічного забезпечення, супроводу освітнього процесу, спрямованих на формування професійно-значущих якостей менеджерів освіти у процесі магістерської підготовки;

- включення і вмотивованість педагогічного колективу щодо формування професійно-значущих якостей менеджерів освіти у процесі магістерської підготовки

Висновок. Формування професійно-значущих якостей менеджера освіти у процесі магістерської підготовки як суб'єкта освітнього процесу є однією з умов досягнення майбутнім менеджером освіти професійної майстерності. Формування професійно-значущих якостей майбутнього менеджера освіти бачиться через:

- індивідуалізацію навчання у системі суб' єктсуб'єктних відносин 3 використанням управлінського потенціалу майбутніх менеджерів в освітньому процесі, максимально спрямованих на формування професійно-значущих якостей;

- систему навчально-методичного, технологічного забезпечення, супроводу освітнього процесу, спрямованих на формування професійно-значущих якостей менеджерів освіти у процесі магістерської підготовки;
- включення і вмотивованість педагогічного колективу щодо формування професійно-значущих якостей менеджерів освіти у процесі магістерської підготовки.

Запропонований комплекс педагогічних умов сприятиме ефективному формуванню та розвитку професійно-значущих якостей менеджера освіти у процесі магістерської підготовки.

\section{ЛІТЕРАТУРА}

1. Беликов, В.А. Философия образования личности : деятельностный аспект: монографія. Москва, 2004. 357 с.

2. Дубич К. В. Особистісно орієнтоване виховання студентів в умовах соціокультурного середовища вищого навчального закладу: дис. ... канд. пед. наук : 13.00.07. Рівне, 2007. 267 с.

3. Житник Н. В. Організаційно-педагогічні умови підготовки бакалаврів економіки у коледжі II рівня акредитації: дис. ... канд. пед. наук : 13.00.04. Кривий Ріг, 2002. 233 с.

4. Журавская, Н.В. Профессиональная подготовка специалистов пожарной безопасности в вузах нефтегазовой отрасли с использованием индивидуально-дифференцированного подхода : автореф. дис. ... канд. пед. наук. Санкт-Петербург, 2011. $26 \mathrm{c}$.

5. Козырева, Е.И. Школа педагога-исследователя как условие развития педагогической культуры. Методология и методика естественных наук. Вып. 4. Сб. науч. тр. Омск, 1999. 24 с.

6. Костюшко Ю. О. Педагогічні умови підготовки майбутнього вчителя до міжособистісної взаємодії в ситуації конфлікту: дис. канд. пед. наук : 13.00.04 . Житомир, 2005. $263 \mathrm{c}$.

7. Лысенко, А.В. Психолого-педагогические условия формирования профессиональноценностных ориентаций будущего учителя музыки : дис. ... канд. пед. наук. Майкоп, 2005. 203 с.

8. Малыхин, А.О. Воспитание морального сознания учеников 5-7 классов на уроках трудового обучения : автореф. дис... канд. пед. наук. Киев, 2000. 20 с.

9. Павлов, С.Н. Организационно-педагогические условия формирования общественного мнения органами местного самоуправления : автореф. дис. ... канд. пед. наук. Магнитогорск, 1999. 23 с.

10. Роджерс К. Взгляд на психотерапию. Становление человека. Москва, 1994. С. 153-171.

11. Рутковская, М.В. Формирование мотивов выбора педагогической профессии: автореф. на соискание учёной степени канд. пед. наук: 13.00.01 - общая педагогика, история педагогики и образования. Ленинград, 1955. 14 с. 


\section{ПЕДАГОГГЧНІ УМОВИ ФОРМУВАННЯ ПРОФЕСІЙНО-ЗНАЧУЩИХЯКОСТЕЙ МАЙБУТНІХМЕНЕДЖЕРІВ ОСВІТИ}

12. Сверчков, А.В. Организационно-педагогические условия формирования профессиональнопедагогической культуры будущих спортивных педагогов. Молодой ученый. 2009. №4. С. 279282.

13. Стасюк В. Д. Педагогічні умови професійної підготовки майбутніх економістів у комплексі “школа-вищий заклад освіти”: дис. ... канд. пед. наук : 13.00. Одеса, 2003.280 c.

14. Яковлева, Н.М. Теория и практика подготовки будущего учителя к творческому решению воспитательных задач : дис...д-ра пед. наук. Челябинск, 1992. 403 с.

\section{REFERENCES}

1. Belikov, V.A. (2004). Filosofiya obrazovaniya lichnosti : deyatelnostnyy aspekt: monografiya [Philosophy of personality education: activity aspect: monograph]. Moscow, 357 p. [in Russian].

2. Dubych, K. V. (2007). Osobystisno oriientovane vykhovannia studentiv $\mathrm{v}$ umovakh sotsiokulturnoho seredovyshcha vyshchoho navchalnoho zakladu [Personally oriented education of students in the socio-cultural environment of higher education]. Candidate's thesis. Rivne, 267 p. [in Ukrainian].

3. Zhytnyk, N. V. (2002). Orhanizatsiinopedahohichni umovy pidhotovky bakalavriv ekonomiky u koledzhi II rivnia akredytatsii [Organizational and pedagogical conditions for training bachelors of economics in the college of the II level of accreditation]. Candidate's thesis. Kriviy Rig, 233 p. [in Ukrainian].

4. Zhuravskaya, N.V. (2011). Professionalnaya podgotovka spetsialistov pozharnoy bezopasnosti $\mathrm{V}$ vuzakh neftegazovoy otrasli $\mathrm{s}$ ispolzovaniem individualno-differentsirovannogo podkhoda [Professional training of fire safety specialists in universities of the oil and gas industry using an individually differentiated approach]. Extended abstract of candidate's thesis. St. Petersburg, $26 \mathrm{p}$. [in Russian].

5. Kozireva, E.Y. (1999). Shkola pedahohayssledovatelia kak uslovye razvytyia pedahohycheskoi kulturi [School of the teacher-researcher as a condition for the development of pedagogical culture]. Collection of scientific papers. Vol. 4. Omsk, 24 p. [in Russian].

6. Kostiushko, Yu. O. (2005). Pedahohichni umovy pidhotovky maibutnoho vchytelia do mizhosobystisnoi vzaiemodii v sytuatsii konfliktu [Pedagogical conditions of preparation of the future teacher for interpersonal interaction in a conflict situation]. Candidate's thesis. Zhytomyr, 263 p. [in Ukrainian].

7. Lysenko,A.V.(2005). Psikhologo-pedagogicheskie usloviya formirovaniya professionalno-tsennostnykh orientatsiy budushchego uchitelya muzyki [Psychological and pedagogical conditions for the formation of professional and value orientations of the future music teacher]. Candidate's thesis. Maykop, 203 p. [in Russian].

8. Malykhin, A.O. (2000). Vospitanie moralnogo soznaniya uchenikov 5-7 klassov na urokakh trudovogo obucheniya [Raising the moral consciousness of students in grades 5-7 in labor training lessons]. Extended abstract of candidate's thesis. Kyiv, 20 p. [in Ukrainian].

9. Pavlov, S.N. (1999). Organizatsionnopedagogicheskie usloviya formirovaniya obshchestvennogo mneniya organami mestnogo samoupravleniya [Organizational and pedagogical conditions for the formation of public opinion by local government bodies]. Extended abstract of candidate's thesis. Magnitogorsk. 23 p. [in Russian].

10. Rodzhers, K. (1994). Vzglyad na psikhoterapiyu. Stanovlenie cheloveka [A look at psychotherapy. Becoming a man]. Moscow, pp. 153-171. [in Russian].

11. Rutkovskaya, M.V. (1955). Formirovanie motivov vybora pedagogicheskoy professii [Formation of motives for choosing a teaching profession]. Extended abstract of candidate's thesis. St. Petersburg, 14 p. [in Russian].

12. Sverchkov, A.V. (2009). Organizatsionnopedagogicheskie usloviya formirovaniya professionalnopedagogicheskoy kultury budushchikh sportivnykh pedagogov [Organizational and pedagogical conditions for the formation of professional and pedagogical culture of future sports teachers]. "Young scientist". Scientific journal. No.4, pp. 279-282. [in Russian].

13. Stasiuk, V. D. (2003). Pedahohichni umovy profesiinoi pidhotovky maibutnikh ekonomistiv $\mathrm{u}$ kompleksi “shkola-vyshchyi zaklad osvity" [Pedagogical conditions of professional training of future economists in the complex "school-higher educational institution"]. Candidate's thesis. Odesa, 280 p. [in Ukrainian].

14. Yakovleva, N.M. (1992). Teoriya i praktika podgotovki budushchego uchitelya k tvorcheskomu resheniyu vospitatelnykh zadach [Theory and practice of preparing a future teacher for the creative solution of educational problems]. Doctor's thesis. Chelyabinsk, 403 p. [in Russian].

Стаття надійшла до редакції 29.10.2020

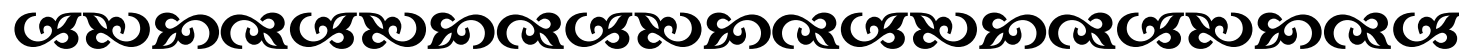

